Status Report 2016-2019

\title{
Tectonics of Sikkim and Eastern Himalaya
}

SAIBAL GUPTA* and NARAYAN BOSE ${ }^{1}$

Dept. of Geology \& Geophysics, Indian Institute of Technology Kharagpur, West Bengal 721 302, India

(Received on 02 September 2019; Accepted on 29 September 2019)

\begin{abstract}
In India, the Eastern Himalaya broadly refers to the region east of Bhutan, and conventionally, Darjeeling and Sikkim are generally included within its domain. This report is a compilation of some of the publications since 2016, made by, or in collaboration with Indian scientists who have discussed various geoscientific aspects of the Eastern Himalaya. From the stand-point of the geological input to tectonic framework, studies dealing with structural, metamorphic and geophysical aspects have been compiled in this report, based on the publications from Darjeeling-Sikkim and Arunachal Himalayas, which are the Indian components of the Eastern Himalaya.
\end{abstract}

\section{Darjeeling-Sikkim Himalaya (DSH)}

\section{Structure}

Microstructural investigations by Ghosh et al. (2016) record the dominance of bulging recrystallization near the Daling Thrust (DT; in the Lesser Himalaya), which gradually changes to sub-grain rotation away from DT. In their tectonic model, this increase in deformation temperature away from DT has been correlated to the variations in flow-stress (16-59 MPa) and strain-rate $\left(10^{-12}-10^{-14} \mathrm{~s}^{-1}\right)$. Based on field studies and balanced cross sections, Parui and Bhattacharya (2018) reported $\sim 403 \mathrm{~km}$ of shortening in the eastern part of the DSH, at the average rate of $\sim 18 \mathrm{~mm} \mathrm{yr}^{-1}$. As the basement ramp is higher in the western DSH $(\sim 2 \mathrm{~km})$ than the eastern DSH $(\sim 0.35 \mathrm{~km})$, the Lesser Himalayan duplex is exposed in the western part only. Along with the field documentation of pre-Himalayan tectono-magmatic features in the Lesser Himalaya, Acharyya et al. (2017) reported a $\sim 1850 \mathrm{Ma}$ Ar-Ar muscovite cooling age for the pegmatites that intruded the Daling Group. Based on field observations and analogue modeling, Ghosh et al. (2018) concluded that the mechanically weak Gondwana sequence played the key role in the localization of the Main Boundary Thrust and Daling Thrust (Location 3 in Fig. 1). Bose et al. (2019) documented back-structures (i.e. exposure-scale structures showing shear senses similar to back-thrusts) from the Lesser Himalayan part of the DSH and correlated the observation with structures on the regional-/local- scale. From the faultslip analyses conducted on the two splays of MBT in the DSH, Patra and Saha (2019) commented on the pre-Himalayan and Himalayan deformation pattern in this region. Pre-Himalayan NE-SW brittle extension was followed by three stages of Himalayan deformation, which includes thrusting events followed by younger strike-slip movements. Singh et al. (2017a) conducted OSL dating of the terraces on both banks, present at the confluence of Tum Thang Khola and Tista Rivers (Location 14 in Fig. 1). The authors detected $45 \mathrm{ka}$ and $11.9 \mathrm{ka}$ events that uplifted earlier terraces T3 and T2, respectively. The warping in recent terraces $\mathrm{T} 1$ and $\mathrm{T} 0$ represent their tectonically active nature.

To investigate the Main Central Thrust (MCT) along the Teesta River valley, Mukhopadhyay et al. (2017) incorporated field, microstructural studies with $\varepsilon_{\mathrm{Nd}}$ and U-Pb geochronology (zircon and monazite) studies. The deformation mechanism in the MCT differs from that of the underlying Lesser Himalayan and overlying Higher Himalayan Crystalline Sequence rocks. The authors also report that the fault zone experienced peak metamorphism $\left(750-800^{\circ} \mathrm{C}\right)$ before the intense faulting at $20 \mathrm{Ma}\left(450-700^{\circ} \mathrm{C}\right)$, which was followed by an isolated, $11 \mathrm{Ma}$ brittle phase. Based

*Author for Correspondence: E-mail: saibl2008@gmail.com 
on field observations and micro-tectonic analyses Chakraborty and Mukul (2019) presented a conceptual model to delineate the structural break representing the Main Central Thrust in the DSH. Their model shows the MCT to be a mappable shear zone in this region, in spite of having spatially varying thickness along and across the strike.

Srivastava et al. (2017) used Real Time Kinematic Global Navigation Satellite Systems data along with field studies to understand various tectonogeomorphic features of the frontal part of the Himalayan orogen exposed at the Gorubathan Recess and Dharan Salient (Locations 15a,b, respectively, in Fig. 1). These authors documented geomorphic features (e.g. warping, geomorphic scarps, topographic growth etc.) formed in response to activity along the Ramgarh Thrust, which defines the orogenic front in this region. Based on the long-time series (1998-2009) of geodetic and static GPS dataset, Mukul et al. (2018) concluded that the Lesser and Higher Himalayas equally share the $\sim 9 \mathrm{~mm} \mathrm{yr}^{-1}$ convergence rate. The authors also postulated the presence of a transverse fault that causes the variation in GPS velocities in the eastern and western parts of the DSH. To address the exceptional dominance of strike-slip seismicity in the DSH, Sunil Kumar et al. (2019) produced a slip-distribution model following the 18September-2011 $\mathrm{M}_{\mathrm{w}} 6.9$ Sikkim earthquake. Their kinematic source process modeling refers to a steep NE-SW sinistral source zone within the underthrust brittle Indian plate. They also report that the transpressive stress regime in the crust changes to a pure strike-slip regime in the mantle.

Thirunavukarasu et al. (2017) used data from local earthquakes recorded by the Sikkim broadband seismograph network to interpret structural heterogeneity and active faults within the crust, and an actively deforming hotter lithosphere beneath the mountain belt. Data from this network also enabled Paul and Mitra (2017) to identify ramps below Peling and Rangit that are responsible for the arcuate nature of the thrust outcrops in these two regions. Importantly, they identified that the underthrust Indian continental crust below Sikkim was 35-42 km thick. Mitra et al. (2018) also attempted to present a comprehensive model of the crustal structure north and south of the Shillong Plateau, encompassing most of northeast India and Bangladesh. Below the eastern
Himalaya, north of the plateau, the Moho was interpreted to show a distinct flexure, dipping $30^{\circ}$ towards north.

\section{Metamorphism}

Studying the Lesser Himalayan rocks at Rangli Rangliot (Location 1 in Fig. 1), Prakash and Tewari (2016) discussed the P-T evolution of metamorphic the rocks in the area using TWEEQU, PerpleX, and petrogenetic grids in the KFMASH system. The reported clockwise P-T-t path has been attributed to decompression of the crust following peak metamorphism at $590^{\circ} \mathrm{C}$ and 5.8 kbar. Tewari and Prakash (2016) studied polyphase deformation and Barrovian metamorphism related to the MCT zone exposed near the Darjeeling-Mangpu region (Location 2 in Fig. 1). Peak temperatures of $570^{\circ} \mathrm{C}$ (garnet zone) and $780^{\circ} \mathrm{C}$ (staurolite zone), peak pressure ranging from 5-7.5 kbar were obtained from geothermobarometric studies. The authors support that the channel flow aided by focused denudation is operating the exhumation process in this region. Subsequently, Tewari and Prakash (2017) incorporated thermobarometry, pseudosection modeling and SHRIMP U-Pb chronology analyses while studying crustal melting in migmatites near Darjeeling (Location 2 in Fig. 1). They obtained peak metamorphic conditions at $7.2 \pm 0.5 \mathrm{kbar}$ and $775 \pm$ $20{ }^{\circ} \mathrm{C}$, with evidence of crustal melting at $21 \mathrm{Ma}$. Prakash et al. (2017) applied Perple_X pseudosection modeling in the MnNCKFMASHTO system, and winTWQ results to integrate the deformation episodes $\left(D_{1}, D_{2}\right.$ and $\left.D_{3}\right)$ with metamorphic phases $\left(M_{1} a, M_{1} b\right.$ and $\mathrm{M}_{2}$ ) in the Barrovian sequence in the Lesser Himalaya near Darjeeling (Location 2 in Fig. 1). The authors inferred that the regional syn-tectonic low grade M1a phase, (started with D1) and the regional static post-tectonic M1b phase (between D1 and D2) represent the prograde phases, whereas the retrograde M2 phase took place between the D2 and D3 episodes.

Chakraborty et al. (2016) reviewed the tectonothermal evolution of the Lesser- \& Higher Himalayan sequences in the DSH. Their thermomechanical models involving geochronological and geospeedometry results indicate that the Greater Himalayan Sequence, which is made up of at least two protolith blocks with different P-T-t histories, had 
a different protolith and metamorphic history from that of the Lesser Himalaya. Based on the data gathered from previous studies, Chakraborty et al. (2017) provided a model explaining the nature of tectonic deformation acting in the DSH. In their model, both channel flow (without funnel effect; at higher temperatures) and critical taper (wedge tectonics; at lower temperatures) were operative in this region. However, these two stages were bridged by a deformation phase involving faulting and visco-plastic flow.

\section{Arunachal Pradesh (AP)}

\section{Structure}

Goswami et al. (2016) studied the mylonitized Abor volcanics (Location 6 in Fig. 1) along a branch of the Main Boundary Thrust, exposed at Siang Valley, Arunachal Pradesh. Based on the field evidence, they concluded that these volcanics were generated during oblique-slip thrusting under the influence of the compression exerted by Burmese plate. Singh et al. (2019) studied the Abor volcanics of the Eastern Himalayan Syntaxis (Location 11 in Fig. 1). Merging of the results of $\mathrm{U}-\mathrm{Pb}$ geochronology (zircon), $\mathrm{Hf}$ isotopes, $\mathrm{XRF}$ and LA-ICPMS analyses indicate that these volcanics were emplaced at $\sim 132$ Ma during the initial stage of Gondwana break-up under the influence of Kerguelen Plume. Based on field examples and morphometric calculations, Bhakuni et al. (2017) emphasize the role of transverse faults and their interaction with the Himalayan thrusts in the development of neotectonic geomorphic features along the Himalayan mountain front in eastern Arunachal Pradesh. Detailed investigation of fractures by Basa et al. (2019) from a fault-bend fold at the Main Boundary Thrust sheet (Location 8 in Fig. 1), Arunachal Lesser Himalaya, shows that fracture spacing is a scale-independent process, but the coefficients of the variation of spacing $\left(\mathrm{C}_{\mathrm{V}}\right)$ is not. Field studies on the Bomdila Gneiss (Location 7 in Fig. 1), Arunachal Lesser Himalaya by Singh et al. (2017b) have led to the demarcation of three deformation phases. The obtained magnetic fabric (SE plunging and sub-horizontal) does not match with any mesoscale foliation, but parallels the $\mathrm{F}_{3}$ axial plane. Based on this example, the authors conclude that anisotropy of magnetic susceptibility (AMS) study is a helpful tool in figuring out the young/weak deformational phases, which leave no signature in the mesoscopic scale.

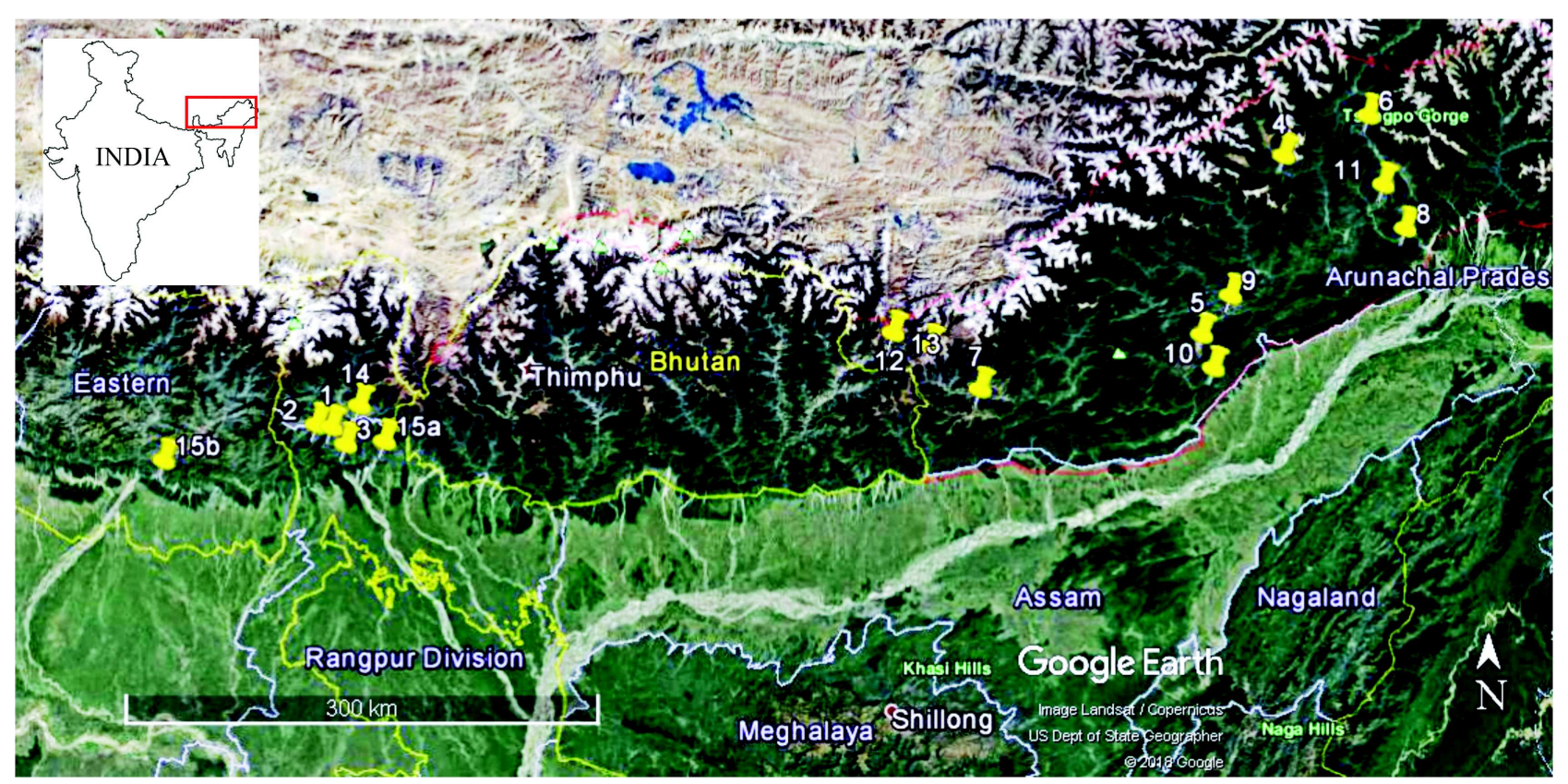

Fig. 1: Google Earth satellite imagery showing the study locations for the following publications mentioned in this report: 1. Prakash and Tewari (2016), 2. Tewari and Prakash (2017), 3. Ghosh et al. (2018), 4. Clarke et al. (2016), 5. Bikramaditya et al. (2018), 6. Goswami et al. (2016), 7. Singh et al. (2017b), 8. Basa et al. (2018), 9. Adlakha et al. (2018), 10. Sharma et al. (2018), 11. Singh et al. (2019), 12. Srivastava and Samal (2019), 13. Taye and Rakshit (2019), 14. Singh et al. (2017a), 15a, b. Srivastava et al. (2017) 
Goswami et al. (2018) have described various tectonic features (such as ramp-flat geometry, splay thrusts etc.) from the Siwaliks exposed along the Kameng River section. From field (Location 13 in Fig. 1) and morphotectonc analyses, Taye and Rakshit (2019) deciphered that the Tawang River flows over a region of complex structural configuration. Based on Apatite Fission Track and (U-Th)/He Zircon ages from the Siang Valley, AP, Salvi et al. (2017) predicted the presence of an unmapped fault. The authors also support that, since late Pliocene, tectonic-erosion relationship played a key role in shaping up the physiography of the studied location. However, Adlakha et al. (2018) obtained the AFT ages to study the exhumation history of a synformal nappe (Location 9 in Fig. 1) in the Higher Himalaya, AP. The results indicate slow exhumation $(0.25 \pm 0.12$ to $0.69 \pm 0.25$ $\mathrm{mm} \mathrm{a}^{-1}$ ) since Middle-Late Miocene. The authors discarded any link between climate induced focused erosion and tectonic deformation. There are a few geophysical studies that provide information on the subsurface structure of the Arunachal Himalayas; e.g., Priestley et al. (2019) reviewed the seismological studies to understand the crustal architecture of the Himalayas at four representative areas including Darjeeling-Sikkim and Bhutan-Northeastern Himalayas.

\section{Igneous and Metamorphic Studies}

Basic petrological and geochemical characterization of the granitoids in this area is still in progress. Bhattacharjee and Nandy (2017) studied the following four types/ episodes of granite activity in the western Arunachal Pradesh: $i$. Bomdila Granite - convergent plate margin, where mixing of crustal and mantle sources took place. ii. Zimithang Granite - syncollisional setting; iii. Salari Granite - volcanic arc, $i v$. syn-collisional leucogranite intrusion in the Greater Himalayan rocks. Metagranitoids from the Subansiri region were studied by Bikramaditya et al. (2018) using U-Pb geochronology, Hf isotopes and geochemical analyses. These granitoids were believed to have originated by partial melting of the Indian passive margin metasediments, and were emplaced during 516-486 Ma. Sharma et al. (2018) described the petrography of the volcanic rocks (mostly basaltandesite and trachite) associated with the Gondwana Group rocks exposed near the Main Boundary Thrust, in and around Lichi area (Location 10 in Fig. 1). The geochemistry of these granites, including major oxides, REE and trace element analyses, suggest a highly calc-alkaline nature, but with signatures both of a pristine MORB and a volcanic arc set-up. Through geochemical analyses of Palaeoproterozoic mafic intrusives from Western Arunachal Pradesh (Location 12 in Fig. 1), Srivastava and Samal (2019) postulated the presence of a large igneous province at $\sim 1.9 \mathrm{Ga}$. Petrographic and geochemical studies conducted on the Palaeoproterozoic pelites and quartzites of the Bomdila area (Location 7 in Fig. 1) by Rashid et al. (2019) indicate the presence of Precambrian felsic crust in this region.

In contrast to these recent igneous studies, metamorphic studies on the area are limited. Clarke et al. (2016) studied the inverted metamorphic sequence located along the Main Central Thrust zone at the Siang Antiform, Arunachal Pradesh. Based on the phase relationships in the NCKFMASHTO system, in conjunction with SHRIMP U-Th-Pb zircon and monazite dating, they constrained the timing of three phases of deformation: i. $>8 \mathrm{kbar}$ at $\sim 550^{\circ} \mathrm{C}$, ii. $\sim 640{ }^{\circ} \mathrm{Cat} \sim 8.5 \mathrm{kbar}$ (c. $18.5 \mathrm{Ma}$ ), iii. $\sim 10 \mathrm{kbar}$ at $\sim 750{ }^{\circ} \mathrm{C}$ (c. $21.5 \mathrm{Ma}$ ).

\section{Current Research Status}

This compilation is a status report of the recent (201619) studies on the Tectonics of Eastern Himalaya. Although an attempt has been made to incorporate accessible contributions made by Indian geoscientists on the subject, it is possible that some studies have not been mentioned due to oversight; this is completely inadvertent, and we apologize for any such omissions. Nevertheless, our efforts do indicate a significant advance in the knowledge related to the tectonics of Darjeeling-Sikkim Himalaya, including information on subsurface structures. On the other hand, the Arunachal Himalayas are still relatively untapped, and remain a promising target for further investigations from the viewpoint of structure, metamorphism and subsurface structure. The Arunachal Himalaya remains the most prospective region for future research on the tectonics of Eastern Himalaya.

\section{Acknowledgement}

SG thanks Profs. D. M. Banerjee and S. Dasgupta for the invitation to compile this status report. 


\section{References}

Acharyya S K, Ghosh S, Mandal N, Bose S andP ande K (2017) Pre-Himalayan tectono-magmatic imprints in the Darjeeling-Sikkim Himalaya (DSH) constrained by ${ }^{40} \mathrm{Ar} /$

${ }^{39}$ Ar dating of muscovite Journal of Asian Earth Sciences 146 211-220

Adlakha V, Patel R C, Kumar A and Lal N (2018) Tectonic control over exhumation in the Arunachal Himalaya: new constraints from Apatite Fission Track Analysis In: Sharma $\mathrm{R}$, Villa I M and Kumar S (Eds) Crustal Architecture and Evolution of the Himalaya-Karakoram-Tibet Orogen Geological Society of London Special Publications 481 DOI: $10.1144 / \mathrm{SP} 481.1$

Basa A, Ahmed F, Bhattacharyya K and Roy A (2019) Evolution and characterization of fracture patterns: Insights from multi-scale analysis of the Buxa dolomite in the Siang Valley, Arunachal Lesser Himalayan fold-thrust belt Journal of Structural Geology 123 54-66

Bhakuni S S, Kothyari G C, Luirei K and Imsong W (2016) Transverse tectonic structural elements across Himalayan mountain front: Implication of superposed landform development on analysis of neotectonics, eastern Arunachal Himalaya, India Geomorphology 282 176-194

Bhattacharjee S and Nandy S (2017) Petrology and geochemistry of the Himalayan granites from Western Arunachal Pradesh Indian Journal of Geosciences 71 439-448

Bikramaditya R K, Singh A K, Chung S L, Sharma R and Lee H Y (2018) Zircon $\mathrm{U}-\mathrm{Pb}$ ages and $\mathrm{Lu}-\mathrm{Hf}$ isotopes of metagranitoids from the Subansiri region, Eastern Himalaya: implications for crustal evolution along the northern Indian passive margin in the early Paleozoic In: Sharma R, Villa I M and Kumar S (Eds) Crustal Architecture and Evolution of the Himalaya-Karakoram-Tibet Orogen Geological Society of London Special Publications 481 DOI: $10.1144 / \mathrm{SP} 481.7$

Bose N and Mukherjee S (2019) Field documentation and genesis of back-structures in ductile and brittle regimes from the foreland part of a collisional orogen: examples from the Darjeeling-Sikkim Lesser Himalaya, India International Journal of Earth Sciences 108 1333-1350

Chakraborty S, Anczkiewicz R, Gaidies F, Rubatto D, Sorcar N, Faak K, Mukhopadhyay D K and Dasgupta S (2016) A review of thermal history and timescales of tectonometamorphic processes in Sikkim Himalaya (NE India) and implications for rates of metamorphic processes Journal of Metamorphic Geology 34 785-803

Chakraborty S, Mukhopadhyay D K, Chowdhury P, Rubatto D, Anczkiewicz R, Trepmann C, Gaidies F, Sorcar N and
Dasgupta S (2017) Channel flow and localized fault bounded slice tectonics (LFBST): insights from petrological, structural, geochronological and geospeedometric studies in the Sikkim Himalaya, NE India Lithos 282 464-482

Chakraborty S and Mukul M (2019) New Insights into the Position and Geometry of the Main Central Thrust from Sikkim, Eastern Himalaya Journal of Geology 127 289322

Clarke G L, Bhowmik S K, Ireland T R, Aitchison J C, Chapman S L and Kent L (2016) Inverted Oligo Miocene metamorphism in the Lesser Himalaya Sequence, Arunachal Pradesh, India; age and grade relationships Journal of Metamorphic Geology 34 805-820

Ghosh S, Bose S, Mandal N and Das A (2018) Control on frontal thrust progression by the mechanically weak Gondwana horizon in the Darjeeling-Sikkim Himalaya Tectonophysics 727 12-27

Ghosh S, Bose S, Mandal N and Dasgupta S (2016) Dynamic recrystallization mechanisms and their transition in the Daling Thrust (DT) zone, Darjeeling-Sikkim Himalaya Tectonophysics 674 166-181

Goswami T K, Bezbaruah D, Mukherjee S, Sarmah R K and Jabeed S (2018) Structures and morphotectonic evolution of the frontal fold-thrust belt, Kameng river section, Arunachal Himalaya, India Journal of Earth System Science 127 1-11

Goswami T K, Bhattacharyya P and Bezbaruah D (2016) Myloniticvolcanics near Puging, Upper Siang district, Arunachal Pradesh: Evidence of oblique-slip thrusting Journal of Earth System Science 125 1205-1214

Mitra S, Priestley K, Borah K and Gaur V (2018) Crustal Structure and Evolution of the Eastern Himalayan Plate Boundary System, Northeast India Journal of Geophysical Research: Solid Earth 123 621-640

Mukhopadhyay D K, Chakraborty S, Trepmann C, Rubatto D, Anczkiewicz R, Gaidies F, Dasgupta S and Chowdhury P (2017) The nature and evolution of the Main Central Thrust: Structural and geochronological constraints from the Sikkim Himalaya, NE India Lithos 282 447-463

Mukul M, Jade S, Ansari K,Matin A and Joshi V (2018) Structural insights from geodetic Global Positioning System measurements in the Darjiling-Sikkim Himalaya Journal of Structural Geology 114 346-356

Patra A and Saha D (2019) Stress regime changes in the Main Boundary Thrust zone, Eastern Himalaya, decoded from fault-slip analysis Journal of Structural Geology 120 2947 
Paul H and Mitra S (2017) Three-Dimensional crustal architecture beneath the Sikkim Himalaya and its relationship to active deformation Journal of Geophysical Research: Solid Earth $1227860-7878$

Parui C and Bhattacharyya K (2018) Duplex and along-strike structural variation: A case study from Sikkim Himalayan fold thrust belt Journal of Structural Geology 113 62-75

Prakash D and Tewari S (2016) Garnet-staurolite-mica schist from RangliRangliot, Eastern Himalaya: Constraints from phase equilibria and Thermobarometry Journal of the Geological Society of India 87 679-690

Prakash D, Tewari S and Singh P C (2017) Prograde Barrovian metamorphism along Darjeeling-Tista transect, Eastern Himalaya, India: constraints from textural relationship, phase equilibria and geothermobarometry Geological Journal 53 243-281

Priestley K, Ho T and Mitra S (2019) The crust structure of the Himalaya: a synthesis. In:Treloar P J and Searle M P (Eds) Himalayan Tectonics: A Modern Synthesis. Geological Society of London Special Publications $\mathbf{4 8 3}$ DOI: $10.1144 /$ SP483-2018-127

Rashid S A, Ahmad S, Islam N and Ganai J A (2019) Precambrian Crustal History Unraveled from the Geochemical Studies of Post-Archean Rocks, Arunachal Pradesh, NE Lesser Himalaya In: Mondal M E A(Ed) Geological Evolution of the Precambrian Indian Shield. Springer, Cham pp 551575

Salvi D, Mathew G and Kohn B (2017) Rapid exhumation of the upper Siang Valley, Arunachal Himalaya since the Pliocene Geomorphology 284 238-249

Sharma N M, Ahmed R S and Bhattacharyya P (2018) Petrography and Geochemistry of the Volcanics in and Around Lichi Area, Papumpare District, Arunachal Pradesh, India Journal of Applied Geochemistry 20 264-274

Singh AK, Chung S L, Bikramaditya R, Lee HY and Khogenkumar $\mathrm{S}$ (2019) Zircon U-Pb geochronology, Hf isotopic compositions, and petrogenetic study of Abor volcanic rocks of Eastern Himalayan Syntaxis, Northeast India: Implications for eruption during breakup of Eastern Gondwana Geological Journal DOI: 10.1002/gj.3477
Singh AK, Pattanaik J K and Jaiswal M K (2017a) Late Quaternary evolution of Tista River terraces in Darjeeling-Sikkim-Tibet wedge: Implications to climate and tectonics Quaternary International 443 132-142

Singh R B, Singh A K, Sen K and Sangode S J (2017b) Detection of a weak late-stage deformation event in granitic gneiss through anisotropy of magnetic susceptibility: implications for tectonic evolution of the Bomdila Gneiss in the Arunachal Lesser Himalaya, Northeast India Geological Magazine 154 476-490

Srivastava R K and SamalA K (2019) Geochemical characterization, petrogenesis, and emplacement tectonics of Paleoproterozoic high Ti and low Ti mafic intrusive rocks from the western Arunachal Himalaya, northeastern India and their possible relation to the $\sim 1.9 \mathrm{Ga}$ LIP event of the Indian shield Geological Journal 54 245-265.

Srivastava V, Mukul M and Mukul M (2017) Quaternary deformation in the Gorubathan recess: Insights on the structural and landscape evolution in the frontal Darjiling Himalaya Quaternary International 462 138-161

Sunil Kumar T C, Earnest A, Silpa K and Andrews R (2019) Rupture of the Indian slab in the $2011 \mathrm{Mw} 6.9$ Sikkim Himalaya earthquake and its tectonic implications Journal of Geophysical Research: Solid Earth 124 2623-2637

Taye C D and Rakshit R (2018) Morphotectonic Study of Tawang River Basin, Tawang District Arunachal Pradesh, NE India Earth Science India 11 11-22

Tewari S and Prakash D (2016) Geothermobarometry and Barrovian Metamorphism of Darjeeling-Mangpu Region, Eastern Himalaya In: Raju N J (Ed) Geostatistical and Geospatial Approaches for the Characterization of Natural Resources in the Environment Springer, Cham pp. 523526.

Tewari S and Prakash D (2017) Age of crustal melting in Higher Himalayan Crystalline Sequence (Darjeeling, Eastern Himalaya): Constraints from SHRIMP UPbgeochronology Geological Journal 53 1516-1525

Thirunavukarasu A, Kumar A and Mitra S (2017) Lateral variation of seismic attenuation in Sikkim Himalaya Geophysical Journal International 208 257-268. 